\title{
Immunology of Infection
}




\title{
IMMUNOLOGY AND MEDICINE SERIES
}

\author{
International Advisory Board \\ Nicolas E. Bianco, Caracas, Venezuela \\ Stefano Bombardieri, Pisa, Italy \\ Manfred P. Dierich, Innsbruck, Austria \\ Janos Gergely, Göd, Hungary \\ Hidechika Okada, Nagoya, Japan \\ Ronald Penny, Sydney, Australia \\ Norman Talal, San Antonio, Texas, USA
}




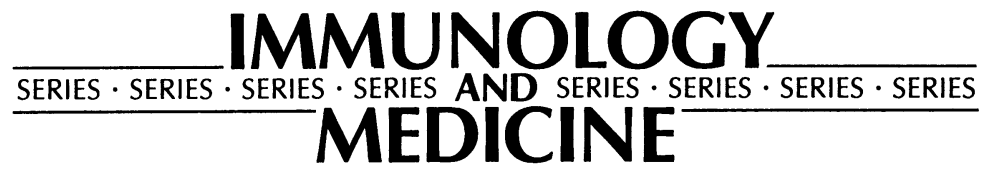

Volume 25

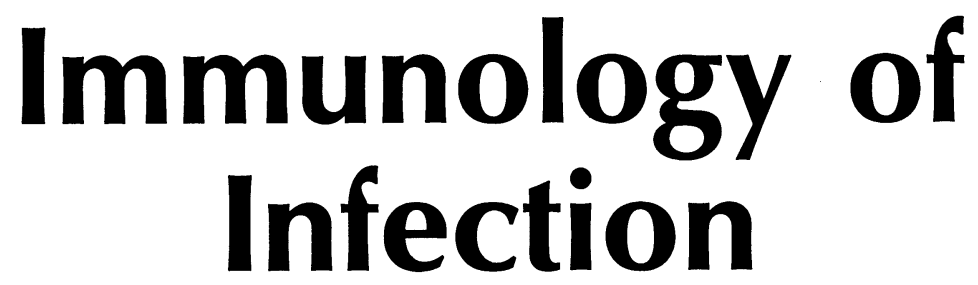

Edited by

J. G. P. Sissons

Department of Medicine University of Cambridge

Cambridge, UK
L. K. Borysiewicz

Department of Medicine University of Wales College of Medicine Cardiff, UK

\section{J. Cohen}

Department of Infectious Diseases and Bacteriology

Royal Postgraduate Medical School

Hammersmith Hospital

London, UK

Series Editor: K. Whaley

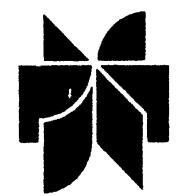

SPRINGER SCIENCE+BUSINESS MEDIA, B.V. 


\section{Distributors}

for the United States and Canada: Kluwer Academic Publishers, PO Box 358, Accord Station, Hingham, MA 02018-0358, USA

for all other countries: Kluwer Academic Publishers Group, Distribution Center, PO Box 322, 3300 AH Dordrecht, The Netherlands

A catalogue record for this book is available from the British Library.

ISBN 978-94-010-4626-8

\section{Library of Congress Cataloging-in-Publication Data}

Immunology of infection / edited by J.G.P. Sissons, L. Borysiewicz, J. Cohen.

p. cm.-(Immunology and medicine series: v. 25)

Includes bibliographical references and index.

ISBN 978-94-010-4626-8 ISBN 978-94-011-1430-1 (eBook)

DOI 10.1007/978-94-011-1430-1

1. Infection-Immunological aspects. I. Sissons, J.G.P. II. Borysiewicz, L. III. Cohen, J. (Jon), 1949- IV. Series.

[DNLM: 1. Infection-immunology. 2. Immunity. W1 IM53BI v. 25 1994 / QW 70013352 1994]

RB153.I46 1994

$616^{\prime} .047-\mathrm{dc} 20$

DNLM/DLC

for Library of Congress

94-27318

\section{Copyright}

(C) 1994 Springer Science+Business Media Dordrecht

Originally published by Kluwer Academic Publishers in 1994

Softcover reprint of the hardcover 1st edition 1994

All rights reserved. No part of this publication may be reproduced, stored in a retrieval system, or transmitted in any form or by any means, electronic, mechanical, photocopying, recording or otherwise, without prior permission from the publishers, Springer Science+Business Media, B.V.

Typeset by Lasertext Ltd., Stretford, Manchester, U.K. 


\section{Contents}

Series Editor's Note vii

Preface viii

List of Contributors $\quad$ ix

1 Immunity to bacteria 1

G. A. W. Rook

2 Molecular structure and immune recognition of mycobacteria A. D. M. Rees, A. Mehlert and J. R. Lamb

3 Immunology of fungal infections

K. Bayston, C. Tang and J. Cohen

4 The immune response to virus infection

A. A. Nash and J. G. P. Sissons

5 The immunology and pathogenesis of persistent virus infections

N. Alp and L. K. Borysiewicz

6 Immunopathology of HIV infection

S. Shaunak

7 The immunopathology of viral and bacterial infections J. G. P. Sissons

8 The pattern of infection in immunodeficiency

A. D. B. Webster

9 Immunoprophylaxis and immunotherapy of gram-negative bacterial infections

J. D. Baumgartner and M. P. Glauser 
IMMUNOLOGY OF INFECTION

10 Current and future approaches to vaccination against virus 215 diseases

C. R. Howard

Index 


\section{Series Editor's Note}

The interface between clinical immunology and other branches of medical practice is frequently blurred and the general physician is often faced with clinical problems with an immunological basis and is expected to diagnose and manage such patients. The rapid expansion of basic and clinical immunology over the past two decades has resulted in the appearance of increasing numbers of immunology journals and it is impossible for a nonspecialist to keep apace with this information overload. The Immunology and Medicine series is designed to present individual topics of immunology in a condensed package of information which can be readily assimilated by the busy clinician or pathologist.

K. Whaley, Leicester

May 1994 


\section{Preface}

The immune system has evolved in large part to enable organisms to resist microbial infection. Given this very fundamental relationship between the immune system and infectious microbial agents it is entirely appropriate that a volume in this series should be devoted to the immunology of infection. Microorganisms have long been used as experimental tools by immunologists, and the study of the immune response to viruses and bacteria has contributed much to our understanding of basic immunological mechanisms (for example of the mechanism by which non-self determinants on cells are recognized). However there are of course important practical and clinical reasons for attempting to understand the immunology of infections - these include the needs for rational design of vaccines and to understand the pathogenesis of human infectious diseases.

The last decade or so has seen a resurgence of interest in infectious diseases and a recognition that they remain of importance and pertinence to all areas of medicine. This is not just because of the advent of AIDS, although that has been a major factor - the rise in drug-resistant mycobacterial infections and the recognition of the infectious aetiology of peptic ulcer disease are other illustrations.

It should be made clear that this volume deals with aspects of the immunolgy of bacteria, viruses and fungi - but it does not deal with parasite immunology which it is planned to cover in a separate volume in the series. The emphasis is in general on human infection with reference to experimental models where appropriate. There is no attempt to deal comprehensively with individual infectious diseases, but rather with the principles involved in the immunolgy of the different classes of infectious agent.

The contributors are all chosen for their active involvement and expertise in the fields on which they write. 


\section{List of Contributors}

N. ALP

Department of Medicine

University of Cambridge

Cambridge CB2 2QQ

UK

\section{J. D. BAUMGARTNER}

Service of Internal Medicine

Hôpital de zone

1110 Morges, Switzerland

\section{K. BAYSTON}

Department of Infectious Diseases and Bacteriology

Royal Postgraduate Medical School

Hammersmith Hospital

Du Cane Road

London W12 OHS, UK

\section{K. BORYSIEWICZ}

Department of Medicine

University of Wales College of Medicine

Heath Park

Cardiff, CF4 4XN, UK

\section{J. COHEN}

Department of Infectious Diseases and Bacteriology

Royal Postgraduate Medical School

Hammersmith Hospital

Du Cane Road

London W12 OHS, UK

\section{P. GLAUSER}

Division of Infectious Diseases

Department of Internal Medicine

University Medical Center

Lausanne, Switzerland

\section{R. HOWARD}

Department of Pathology and Infectious

Diseases

The Royal Veterinary College

Royal College Street

London NW1 OTU, UK

\author{
J. R. LAMB \\ Department of Immunology \\ St Mary's Hospital Medical School \\ Praed Street \\ London W2 1YN, UK
}

\section{A. MEHLERT \\ Department of Biochemistry \\ University of Dundee \\ Dundee DD1 4HN, UK}

\begin{abstract}
A. A. NASH
Division of Immunology

Department of Pathology

University of Cambridge

Cambridge, UK
\end{abstract}

\author{
A. D. M. REES \\ Department of Genito-Urinary Medicine \\ and Communicable Diseases \\ St Mary's Hospital Medical School \\ Praed Street \\ London W2 1YN, UK
}

\section{G. A. W. ROOK}

Department of Medical Microbiology

University College London Medical School

67-73 Riding House Street

London W1P 7PP, UK 
IMMUNOLOGY OF INFECTION

\section{S. SHAUNAK}

Department of Infectious Diseases and Bacteriology

Royal Postgraduate Medical School Hammersmith Hospital

Du Cane Road

London W12 OHS, UK

J. G. P. SISSONS

Department of Medicine

University of Cambridge

Cambridge, UK
C. TANG

Nuffield Department of Medicine

John Radcliffe Hospital

Headington

Oxford OX3 9DU, UK

\section{A. D. B. WEBSTER}

Immunodeficiency Research Group

Clinical Research Centre

Watford Road

Harrow

Middlesex HA1 3UJ, UK 